\title{
A Reflexive Account of Reusing Qualitative Data: Beyond Primary/Secondary Dualism
}

\author{
by Libby Bishop \\ University of Essex \\ Sociological Research Online, Volume 12, Issue 3, \\ < http://uww. socresonline.org.uk/12/3/2.html> \\ doi:10.5153/sro. 1553
}

Received: 1 Mar 2006 Accepted: 1 May 2007 Published: 30 May 2007

\begin{abstract}
Though secondary analysis of qualitative data is becoming more prevalent, relatively few methodological studies exist that provide reflection on the actual, not idealised, process. This paper offers a reflexive account of secondary analysis focused on the topic of convenience food and choice. Several phases of the research process are examined: understanding context, defining a subject area, finding data and sampling, later sampling and topic refinement, and relating to transcripts. For each phase, I explore if reusing data is different from using it in the first instance, and if so, how those differences manifest themselves. The paper closes with reflections on the differences, similarities, and relationships between primary and secondary analysis of qualitative data. Although differences exist regarding the researcher-respondent relationship, primary and secondary analyses are more alike than not. The suitability of each approach can only be assessed in light of a particular research question.
\end{abstract}

\section{Keywords: Convenience Food, Data Archives, Qualitative Data, Reflexivity, Data Re-Use, Secondary Analysis}

\author{
Introduction \\ "It is scary to reveal how your mind works" (First entry, personal research diary, BSA food \\ paper, 10 September 2004).
}

1.1This extract is from a research diary that accompanied a study about convenience food that relied on secondary analysis of materials archived at ESDS Qualidata (Bishop, 2005b). As part of my work at ESDS Qualidata, I encourage researchers to deposit data, and thus, also attempt to address their reservations about archiving. While there is general agreement that more documentation and context make data better for reuse (Fielding and Fielding, 2000; Hammersley, 1997), many researchers are reluctant to provide their less-than-polished early and intermediary materials, not wanting to expose false starts, mistakes, etc. I intended the diary to help me be more reflexive about doing qualitative research (Mauthner and Doucet, 2003; Roberts, 1981; Personal Narratives Group, 1989), and in doing so, to enable me to more effectively address concerns of prospective depositors. Researchers' fears of making our thinking transparent are not the only barrier to depositing data. However, the craft of research involves thinking, and exposing how that is done can be unnerving. The research diary raised questions that led to defining the central aim of this paper: to provide a reflexive account of secondary analysis on the topic of convenience food and choice.

1.2 A number of authors have been reflexive about their use of secondary analysis ( Corti and Thompson, 2004; Hinds et al., 1997; Mauthner et al., 1998; Szabo and Strang, 1997). However, most of these were reusing their own data. The desire for more general discussion may have motivated this challenge from Heaton (2004:121):

Clearly there is a need to document in more detail what the process of doing qualitative secondary analysis involves in practice, including methods for re-using different types and sources of data for different purposes, and whether and how informed consent has been obtained for secondary studies.

1.3 More recent examples have included researchers reflecting on their use of others' data (Corti, et al., 2005; Fielding and Fielding, 2000; Savage, 2005a; van den Berg, 2005). This paper deepens these efforts by shifting emphasis from the findings of the reuse study itself and provides instead a reflexive account of its methodology.

1.4 The next section provides a summary of my secondary analysis project. The following section presents an overview of the aims and methods used in the primary studies that provided data for the reuse project. This is followed by a summary of the methodological approach of the secondary analysis project, including 
a discussion of consent and ethics. The remainder of the paper consists of reflections on reusing data by considering several phases of the research process: understanding context, defining the subject area, finding data and sampling, later sampling and topic refinement, and relating to transcripts. The paper closes with reflections on the differences, similarities, and relationships between primary and secondary analysis of qualitative data.

\section{Summary of the secondary analysis project}

2.1 The project used convenience food as a probe to begin examining the de-socialisation of meals eaten at home, i.e., the phenomenon of individuated eating (Bishop, 2005b). It posited that de-socialisation is significant because it represented a growing arrogation of individualism, particularly individual choice, over commensality or sociality. In the contemporary era, neoliberalism—-the belief that markets driven by individual choice are the optimal form of social organisation-is being incorporated into domestic production through the vehicle of "choice" enabled by convenience foods. This phenomenon is part of a long trajectory of market and industrial expansion into the private domain.

2.2 The study used two historical qualitative data sets, Blaxter's Mothers and Daughters (2004), and Thompson's The Edwardians (Thompson, 2005), to examine attitudes and practices about early forms of processed foods and about sociality and food choices at meals. The paper did not attempt to research individuated eating directly. Rather, it began from a more exploratory stance, namely, the need to problematise convenience and choice by exploring the beliefs and practices from which current uses of convenience food may have emerged. From its inception, the paper was intended as a first step in a larger research programme that would be augmented by additional data collection involving interviews with food preparers and observation of food purchase and preparation practices.

\section{Aims and methodologies of the two primary research projects}

\section{Mothers and Daughters}

3.1 The aim of Blaxter and Patterson's (1982) research was to study inter-generational transmission of deprivation using a sample of women in 58 three-generation families and was part of a larger ESRC programme on Transmitted Deprivation. Sampling was purposive: families that remained working class across two generations, grandmother-daughter co-location in the same city, and continuing contact. The study addressed diverse factors, exploring whether health and social histories, attitudes, and health behaviours would affect the health experiences of the children and were possibly transmitted across generations. Nutrition was one of several topics addressed; others were orientations toward medicine, antenatal care, preventive behaviour, use of lay remedies, etc. The study used several types of data: information from longitudinal visits with the mothers, health visitor reports, etc. Other data, including the material archived at ESDS Qualidata, are semi-structured interviews that focused on attitudes and perceptions.

3.2 A year after publishing their book, Blaxter and Patterson (1983) reanalysed their data to study the historical and moral significance of food. They reported on what constituted "good food": specific foods were less important than a "proper" meal, as contrasted with processed foods, or "snackery" (97). They also used their rich intergenerational data to compare the different attitudes and behaviours between grandmothers and their daughters.

\section{The Edwardians}

3.3 There were three aims of the Edwardians project. The first was to establish the most important dimensions of social change in the early twentieth century, with a concentration on issues fundamental to social structure, notably class, gender and age. The second was to explain social change, with particular attention to the respondents own consciousness about it. Finally, it was hoped that oral histories would reveal the details of daily life of ordinary people.

3.4 A quota sample was devised, based on the 1911 census, which totaled 444 people. Six major occupational groups, plus classifications of location, gender and regional distribution were used as the basis for the sample. The respondents were chosen by a variety of means, including through social workers, care homes, personal contact and advertisement. The interviews were conducted by a number of part-time interviewers who used a detailed interview schedule, but were also instructed to be flexible and conversational. Interviews averaged four hours in length. In addition to the complete transcripts, the data were coded according to twenty main themes (e.g., work, leisure, childbirth, school, meals, etc.). There has been extensive reuse of The Edwardians data, but nothing focused specifically on food (http://www.esds.ac.uk/qualidata/online/data/edwardians/original.asp).

\section{Methodological approach of the secondary analysis project}


4.1 I started working at ESDS Qualidata in September 2003 with responsibilities to prepare and enhance data for archiving and web-access, to advise prospective data depositors, and to promote secondary analysis (Bishop, 2005a). I felt obliged to conduct research involving data reuse because it felt both illinformed and vaguely hypocritical to advise and promote without first-hand experience. Second, a move from the US to the UK had sparked a research interest in food, but this represented a major shift away from my previous research in service work. Beginning by re-analysing existing data seemed a useful starting point, akin to an in-depth literature review. The need to explore historical changes in attitudes and practices also made use of existing data plausible (Savage, 2005b). Finally (and more pragmatically) given my employment in ESDS Qualidata, using secondary analysis would be easier to integrate with my "day job" than embarking on primary research.

4.2 Some research questions were stirred by exposure to the data as I helped prepare Blaxter's data from Mothers and Daughters for deposit. There were frequent mentions, usually disparaging, of convenience foods ("tins"). Thompson's data had detailed descriptions of social practices at meals, who ate together, manners, allocation of food, availability and use of tinned foods, and so on. I was interested in contemporary food provisioning practices involving convenience foods and decided the data were rich enough to warrant further investigation.

4.3 In parallel with reading this data, I read exemplars in the sociology of food literature (Charles and Kerr, 1988; de Vault, 1991; Douglas, 1972; Harvey, et al. 2002; Lang, et al. 1996; Mintz, 1985; Murcott, 1982; Murcott, 1995, Murcott, 1998; Warde, 1997). Other authors gave insights into the specifics of convenience and food (Gofton, 1995; Short, 2003; Warde, 1999). After this preliminary data exposure and reading, I generated a list of questions for the research project:

- What range of attitudes toward convenience food is expressed?

- Is use of convenience food always condemned?

- If not, under what conditions is convenience food accepted?

- What reasons are given for its use?

- How do these answers vary by: time period, age of respondent, class?

- What attitudes are expressed about individualism and sociality at meals?

- How are dining practices described?

- Were meals eaten together?

\section{Re-use of Mothers and Daughters}

4.4 From the first collection, Mothers and Daughters, ESDS Qualidata has 46 grandmother interviews-the complete collection (i.e., 46 grandmothers of the original 58 families met the criteria and agreed to participate). Detailed coding was done only on sections that pertained to food, largely in the replies to these three questions from the original interviews:

- Would you say that some people are naturally healthier than others?

- Do you have any sort of recipes that you have for keeping healthy?

- And any particular ideas for keeping children healthy?

If food was not mentioned in the responses to question three, a follow up question was asked, "What about food?" (Blaxter and Patterson, 1983; 96).

4.5 I used computer software, Atlas.ti 5.0, for data management and thematic coding. Coding categories included: types of foods, cooking techniques, attitudes about (and definitions of) good foods, the role of food in health, references to some specific foods (fruits and vegetables), any discussions of good, homemade, and proper food, etc. All mentions of tins, tinned foods, packets, convenience or other processed foods were noted. Related topics, such as alcohol consumption, obesity and slimming, were also coded, as was employment in the food sector and any discussions of gendered division of labour. In general, I selected a keyword to include several terms used by respondents. For example, "slimming" referred to any attempt to lose weight. Some respondents used that term; other mentioned dieting or getting rid of fat. Very little code consolidation or refinement was done. In one instance, soups (and broths) were discussed so often, I created a separate "soup" code and re-read all the intenviews to code all mentions of soup. For detailed analysis, every occurrence of processed food was examined and assigned a rating as positive, negative or neutral. Finally, the data were examined for reasons and justifications given for using convenience food. (See Table 1 reproduced from the secondary analysis paper, Bishop, 2005b.)

Table 1. Analysis of Mothers and Daughters data on tinned food 


\begin{tabular}{|c|c|c|c|c|c|c|c|c|}
\hline & & & & & & & & \\
\hline \multirow[t]{2}{*}{$\begin{array}{l}\mathrm{ID} \\
\text { no. }\end{array}$} & \multirow[t]{2}{*}{$\begin{array}{l}\text { ATTI- } \\
\text { TUDE } \\
\text { TO } \\
\text { TINS } \\
\end{array}$} & \multicolumn{4}{|c|}{$\begin{array}{l}\text { REASONS GIVEN FOR ATTITUDE TOWARD TINNED } \\
\text { FOOD }\end{array}$} & & \begin{tabular}{|l} 
USE \\
OF \\
TINS \\
OK?
\end{tabular} & $\begin{array}{l}\text { UNDER } \\
\text { WHAT } \\
\text { CONDI- } \\
\text { TIONS? }\end{array}$ \\
\hline & & too & taste & $\begin{array}{l}\text { home made } \\
\text { more } \\
\text { nourishing }\end{array}$ & $\begin{array}{l}\text { home made } \\
\text { better }\end{array}$ & other & & \\
\hline $3 g$ & neg & & & $\begin{array}{l}\text { old man does } \\
\text { not believe in } \\
\text { it, no } \\
\text { nourishment }\end{array}$ & $\begin{array}{l}\text { get goodness off } \\
\text { a bone }\end{array}$ & & partial & \begin{tabular}{|l|} 
daughter \\
uses it, but \\
"hardly ever"
\end{tabular} \\
\hline $4 \mathrm{~g}$ & neg & & & & $\begin{array}{l}\text { good, plain food } \\
\text { better }\end{array}$ & & yes & tin of soup \\
\hline $7 \mathrm{~g}$ & neg & $\begin{array}{l}\text { couldn't } \\
\text { afford it }\end{array}$ & & & $\begin{array}{l}\text { good, wholesome } \\
\text { home made } \\
\text { better }\end{array}$ & & yes & $\begin{array}{l}\text { when you're } \\
\text { on your own }\end{array}$ \\
\hline $14 \mathrm{~g}$ & $\begin{array}{l}\text { part } \\
\text { neg }\end{array}$ & & & & & not for babies & & \\
\hline $19 \mathrm{~g}$ & neg & $\begin{array}{l}\text { cld never buy } \\
4-5 \text { tins }\end{array}$ & $\begin{array}{l}\text { frozen } \\
\text { doesn't } \\
\text { taste right }\end{array}$ & $\begin{array}{l}\text { body building } \\
\text { material gone }\end{array}$ & & $\begin{array}{l}\text { wouldn't give it to } \\
\text { husband: we } \\
\text { were not brought } \\
\text { up like that }\end{array}$ & yes & $\begin{array}{l}\text { maybe ok for } \\
\text { daughter if in } \\
\text { a hurry }\end{array}$ \\
\hline $21 \mathrm{~g}$ & mixed & & & & $\begin{array}{l}\text { tin can be good, } \\
\text { but home made } \\
\text { better }\end{array}$ & & $\begin{array}{l}\text { depend } \\
s\end{array}$ & \\
\hline $22 \mathrm{~g}$ & neg & $\begin{array}{l}\text { soup less } \\
\text { expensive }\end{array}$ & & & $\begin{array}{l}\text { home made } \\
\text { better }\end{array}$ & & & \\
\hline $28 \mathrm{~g}$ & neg & & & & $\begin{array}{l}\text { home made more } \\
\text { wholesome }\end{array}$ & $\begin{array}{l}\text { no time for that, } \\
\text { not for babies }\end{array}$ & yes & $\begin{array}{l}\text { what you eat } \\
\text { when you're } \\
\text { young for a } \\
\text { start }\end{array}$ \\
\hline $30 \mathrm{~g}$ & neg & & & healthier & & $\begin{array}{l}\text { no special tins for } \\
\text { babies }\end{array}$ & & \\
\hline $41 \mathrm{~g}$ & neg & $\begin{array}{l}\text { soup less } \\
\text { expensive }\end{array}$ & & & & & maybe & $\begin{array}{l}\text { more } \\
\text { convenient }\end{array}$ \\
\hline $9 \mathrm{gg}$ & neg & & & & soup better & not artificial & yes & $\begin{array}{l}\text { Oxo ok for } \\
\text { soup; tin of } \\
\text { beans ok. } \\
\text { but not tin of } \\
\text { soup }\end{array}$ \\
\hline $63 \mathrm{~g}$ & neg & & $\begin{array}{l}\text { funny } \\
\text { flavour }\end{array}$ & & $\begin{array}{l}\text { home made } \\
\text { better }\end{array}$ & & yes & $\begin{array}{l}\text { occasional } \\
\text { ok }\end{array}$ \\
\hline $67 g$ & neg & cheaper & $\begin{array}{l}\text { better } \\
\text { taste }\end{array}$ & & $\begin{array}{l}\text { prefer home } \\
\text { made }\end{array}$ & & no & $\begin{array}{l}\text { but people } \\
\text { use it for } \\
\text { convenience }\end{array}$ \\
\hline
\end{tabular}

\section{Reuse of The Edwardians}

4.6 I was somewhat familiar with the content of these interviews and had read the published book (Thompson, 1975). Because of the length of the interviews and limited time, only the sections on meals were analysed. There were many questions were asked about foods eaten, how cooking was done, special foods at holidays, home processing (e.g., jam), and behaviours at meals (e.g., who was served first). I have analysed answers to the following questions asked in the original interviews:

- $\quad$ Did they [parents] buy any tinned or dried vegetables or fruit?

- $\quad$ What about tinned meat?

- Could you choose what you wanted to eat from what was cooked or did you have to eat a bit of everything?

- $\quad$ Did all the family sit at the table for the meal?

4.7 Forty-four interviews ( $10 \%$ of the collection) were analysed on responses to the questions listed above. Interviews were chosen to include a diverse range of occupational and regional categories, but the subsample is not strictly representative (because my longer term research plan called for analysing all the data later). Very simple binary coding schemes were used. For example, the question about meals eaten together, the assigned code is based on the tendency across all the meals described for the majority of 
family members to gather. The most common meals for such gatherings were breakfast and tea; often work and school prevented gathering for a mid-day meal.

4.8 The data shed light not on individuated eating directly, which seems to have been largely non-existent at that time, but rather on attitudes toward expressions of individual taste about food to be eaten in a group at

family meals. This question seemed to provide an imperfect, but still useful, indicator of the balance between individual and family tastes at mealtime. A central advantage of The Edwardians data is its size and representativeness. It is possible to pose questions such as: do expressions of individual choice at meals vary by occupation, region or gender? (See Table 2 reproduced from the secondary analysis paper, Bishop, 2005b.)

Table 2. Analysis by occupation of Edwardians data

\begin{tabular}{|l|c|c|c|c|c|c|c|c|}
\hline & \multicolumn{2}{|c|}{$\begin{array}{c}\text { Choice at } \\
\text { meals? }\end{array}$} & \multicolumn{2}{c|}{ Meals together? } & \multicolumn{2}{c|}{ Tinned fruit? } & \multicolumn{2}{c|}{ Tinned Meat? } \\
\hline & Yes & No & Yes & No & Yes & No & Yes & No \\
\hline $\begin{array}{l}\text { Professionals } \\
(6)\end{array}$ & - & 5 & 4 & 1 & 2 & 3 & - & 3 \\
\hline $\begin{array}{l}\text { Employers } \\
\text { \&managers } \\
(6)\end{array}$ & 2 & 2 & 3 & 1 & 1 & 4 & 2 & 3 \\
\hline $\begin{array}{l}\text { Clerical and } \\
\text { Foremen (6) }\end{array}$ & 1 & 4 & 5 & 1 & 2 & 3 & 3 & 3 \\
\hline $\begin{array}{l}\text { Skilled } \\
\text { Manual (8) }\end{array}$ & 3 & 5 & 7 & 0 & 2 & 5 & 2 & 6 \\
\hline $\begin{array}{l}\text { Semi-skilled } \\
\text { manual (8) }\end{array}$ & 1 & 6 & 4 & 3 & 0 & 6 & 2 & 5 \\
\hline $\begin{array}{l}\text { Unskilled } \\
\text { manual (4) }\end{array}$ & 1 & 3 & 3 & 1 & 1 & 1 & - & 2 \\
\hline $\begin{array}{l}\text { Unclassified } \\
(6)\end{array}$ & 3 & 3 & 3 & 1 & 1 & 4 & 0 & 6 \\
\hline & & & & & & & & \\
\hline Total (44) & 11 & 28 & 29 & 8 & 9 & 26 & 9 & 28 \\
\hline
\end{tabular}

\section{Consent and ethics}

5.1 Before turning in detail to the comparison between using and reusing data, a brief discussion of consent is in order. These informants did not explicitly provide consent for archiving and reuse of their data.

Such written consent was not standard practice when these studies were done. For The Edwardians, pseudonyms are used, though in fact participants did not seek anonymity and were sent thank-you letters explaining that their interviews would be generally useful for social history research. For Mothers and Daughters, code numbers are used in place of names. Finally, both collections met the following criteria: the depositor has signed a licence authorizing the UKDA to archive data and related material and any person using the data undertakes (by signing an end user licence) not to disclose harmful information about the participants. Of course, explicit written consent is always preferred, and is now recommended by ESDS Qualidata. However, given the precautions taken and the minimal risks to participants, the data seemed acceptable to use.

5.2 The process of gaining consent for secondary use is similar to gaining consent in exploratory primary research, i.e., studies in which the research questions are not known in advance (Heaton, 2004). The issue then, is not whether the analysis is primary or secondary, but specificity of research purposes known in advance. Much more work is needed to define ethical guidelines in these areas (Bishop, 2005a; Parry and Mauthner, 2004).

5.3 With these summaries of the methods from the primary projects and the approach used for the secondary analysis now in place, the next sections proceed through several phases in the research process and explore similarities, differences and comparisons between using and reusing data.

\section{Context and Recontextualisation}

6.1 Most researchers agree that the potential for reusing qualitative data is dramatically enhanced when extensive context is provided (Fielding, 2004; Heaton, 2004). Specific definitions of context are rare, with van den Berg (2005) one notable exception. Some recent explorations of context are emerging that address its political dimensions (Silva, 2005). Moore (2005:22) provides an extremely useful reframing of the issue 
6.2 At the risk of over-simplification, it is useful to specify some of the components of a recontextualisation process. There are two points in time at which context needs to be considered: the period when the original project was done, and the period for the contemporary project. In each period, there are at least three levels of contexts: the interaction, the situation, and cultural/institutional. In addition, one must consider two sets of research questions: those from the original project and the contemporary ones (Bishop, 2006). Finally, there are research artifacts to consider, typically interview transcripts and audio or video tapes, along with other materials such as research diaries, analytical coding schemes, theorising memos, methods sections of published works, and interviews with the original researcher. Space will permit a discussion of just a few these relationships for the Blaxter and Patterson project.

6.3 The original Mothers and Daughters project has reasonably good documentation: the methods sections of the published studies and an extract from an interview conducted by Paul Thompson of Mildred Blaxter are available in the ESDS Qualidata user guide (Blaxter, 2004; Thompson, 2002). The study was intended

to inform social policy: "It was about health and welfare services you know, and it had to have practical implications" (Blaxter, 2004). There are some clues about the approach to qualitative research. The authors are explicit that multiple dimensions might be revealed, and they did not expect consistency across narratives. Blaxter and Patterson's own reanalysis of their data was spurred by a respondent's comment about "goodness" of food. They analysed their materials to ask "what was the real meaning of this concept and commodity called food?" (Blaxter and Patterson, 1983: 95). Throughout their work, the "discussions of food were all in the context of food for children" (Blaxter, 2006).

6.4 These contextual resources also provide information about the interviews themselves. Interviews were done by two educated, white women. Patterson did the majority of the grandmother interviews. She was from the same area where the families lived. Blaxter praised her ability to gain rapport with the respondents. The study was presented to respondents as being about child-rearing and child-rearing beliefs and practices across generations. Blaxter believes that she and Patterson were perceived as social workers, "no matter what we said" (Blaxter, 2006). There had been regular visits to the families by either Blaxter or Patterson; mothers were interviewed at the end of the six month study.

6.5 What is the significance of this project context, given our very different research questions? All this information is helpful in setting a scene and adds depth to the transcripts. In particular, knowing details of the longitudinal nature of the work places the interviews not as one-time anonymous encounters but suggests that familiar relationships may have formed between researchers and respondents. The most salient element is the fact that health was a central subject of the original interviews (though not the only focus of the overall project). Given that my questions on convenience foods are potentially related to discussions of links between foods and health, this is an area for close examination. The grandmothers' responses must be interpreted knowing these were working class women, many poor, describing their health and nutritional attitudes and practices about their children to researchers.

6.6 For example, in their accounts for not using tinned food, the grandmothers might have emphasised health reasons more than others such as taste or cost, or might have stressed that it was not suitable for children. Given a large set of reasons available, they might have picked the one they felt that would be most readily appreciated by their interviewers. This would be a problem if I had tried to make some claim about the relative importance of these discourses, but in the secondary analysis, my central purpose was simply to document the co-existence of competing discourses about convenience foods: there was strong condemnation of convenience foods, and there were also justifications given for its use. I found multiple reasons given for disliking tinned food, but I attached no weight to the frequency with which various justifications were used.

6.7 Nonetheless, there is a potential pitfall here: what if the overarching context of a project on child-rearing practices prevented some convenience food discourses from being disclosed at all? What if regular consumption of convenience foods by children was not mentioned for fear of incurring condemnation (however well-disguised or subconscious)? And even if rapport with the interviewer was such that such disclosures were possible, respondents inevitably constituted their narratives through existing public discourses. Since the 1970 s or earlier, health had become a growing theme in public policy debates about food. These pressures might have deterred respondents from talking openly about nonconforming practices. This possible suppression of "anti-health" discourses seems both plausible and problematic. What it indicates is that further research (e.g., expanded sample, interview techniques designed to minimise perceptions of judgment being passed, etc.) might expand the set of discourses expressed to justify convenience food. I hope to pursue this idea. For now, it does not undermine the finding that diverse justifications do exist.

6.8 What was going on in society at large that might matter when I analysed this data in 2005 compared to Blaxter and Patterson's (1983) reuse over 25 years earlier? In raising this question, I'm trying to follow the lead set by Savage (2005b) in his reanalysis of data from several Mass Observation surveys. To provide one example, he cites the growing prevalence of market survey research. He takes into account respondents' 
growing familiarity with survey practices in his interpretation of the longitudinal Mass Observation data. For my secondary analysis on convenience and choice, a full history of food and neoliberalism could be deemed relevant. Only by returning to the research questions can the relevant social context be narrowed a bit.

6.9 Warde (1997) defines four antinomies that characterise food discourses: novelty/tradition, health/indulgence, economy/extravagance and convenience/care. During the periods the grandmothers describe, themes of tradition, economy and care were dominant. Tinned food as protection from want was surely more prominent for the grandmothers than would be typical today. In the 21 st century, some of these discourses have shifted, with novelty, health, indulgence, convenience and extravagance more prominent (Ritson and Hutchins, 1995; Warde, 1997). This summary glosses important variations by class, gender and region. In 2005, food's role in health is a dominant discourse and permeates policy, medicine, casual conversation and even recipes (Warde, 1997).

6.10 The dominance of this health discourse has at least one implication for my secondary analysis project: given the historical shifts in perceptions of the meaning of "goodness", it is very clear that criteria for either "good" or "bad" foods are historically situated. I took this into account when examining the Blaxter data. In coding reasons why convenience food was seen as inferior, one code was "homemade-better". This was a general category that gave no specific reason for why homemade was seen as superior. In addition,

there is a code for "homemade-more nutritious". Here, only reasons that specifically identify health or nutrition justifications are included.

\section{Defining a subject area}

7.1 As best I can reconstruct it, three influences—pragmatic, intellectual, and experiential—converged to define my subject area. As discussed above, there were feelings of obligation to gain first-hand experience

with reusing data and pragmatic constraints as to what was feasible in my workplace. Second, my intellectual curiosities about food, convenience, and methodology were aroused by archiving data and reading research accounts and general sociology of food literature. Finally, the experience of moving from San Francisco to Wivenhoe, Essex was highly influential. Even with previous extended visits to the UK, I was not prepared for the poor quality and limited availability of produce, the shelves of crisps and biscuits in grocery aisles, accelerating obesity rates, market concentration in food retailing, and so on. Whether as a

"personal trouble" of finding something edible to make for dinner, or as a "public issue" of hypothesizing correlation between the increasing rates of convenience food use and poor health, I was thinking about food continually. It was a short step from there to starting a research project.

7.2 Best research practice mandates formulating questions, then picking the best tools for the job (Mason, 2002). In the spirit of "owning up" (Bell, 2004), I must confess to shaping some of my initial research interests to conform to a project of data reuse. However, pragmatism is not unique to secondary analysis. In practice, researchers develop more competence in some methods than others; experts in longitudinal surveys are not likely to jump into psychoanalytical interviewing, or vice versa. Most researchers limit their questions to their areas of methodological expertise, even though best practice suggests it is always good to pay attention to these constraints and attempt to free research design from them as much as possible (Mason, 2002). In reality, research is often influenced by any number of pragmatic considerations: the size of ESRC grants, membership on journal editorial boards, current "hot" topics in the discipline, date of the next Research Assessment Exercise, and so on. Very few of these reasons ever make it into the published accounts of methodology.

7.3 Negotiating constraints need not be a failing, whether in primary or secondary research. This is a far more dynamic process than most methods books usually acknowledge: ideas occur, tools are applied, questions shift, new tools are found, new tools uncover new data, and questions are reformulated. Research quality is determined not by the presence or absence of pragmatic choices, but how aware, reflexive and transparent researchers are about the choices made.

\section{Finding and assessing data - sample selection}

8.1 For my reuse project, I limited myself to data available through ESDS Qualidata that had some content on the subject of convenience food. The collections available were rich, yet limitations still had to be addressed. The Mothers and Daughters sample is narrow, including only women in social classes IV and V (partly or unskilled occupations) in one Scottish city. I took this sampling into account, knowing that direct generalisation to a larger population would not be possible. However, from a theoretical perspective, such a sub-sample could be useful. Especially in Britain, convenience food consumption has been equated with laziness, low morals, and lower class behaviour (Gofton, 1995). In light of such claims, it seemed worth a particular focus on the uses of and attitudes about convenience foods expressed by members of lower socio-economic groups themselves.

8.2 With respect to content, the Mothers and Daughters data are highly textured. There were extensive discussions of home-cooked food, as well as comments on tinned and other processed foods.

Respondents commented on the relative "goodness" of home-cooked compared to processed foods. The open-ended style of the questions yielded surprisingly rich descriptions given that the subject of tinned food 
was not central to the original project. The extensive knowledge the interviewer had from other sources (health visitor data) and previous interviews (the study was longitudinal) further deepened the data. Some of the richness might also have been explained by the empathy the interviewer often showed to her subjects. Her "of course" in the extract below shows a compassionate understanding that cost, not lack of maternal care, would explain the small quantities of fruit in the children's diet.

\section{G: ... They didna [didn't] get a lot o' fruit, they only had fruit at New Year time. Cos I couldna afford it ava [approximate meaning, "you see"].}

\section{LP: Of course, it's expensive.}

8.3 Despite the richness of the interviews, ESDS Qualidata has only the grandmother interviews, and that presented limitations. Had I attempted any hypothesis of intergenerational transmission or other comparisons between grandmothers and mothers, this would have been a serious absence. As it was, my explorations could have been significantly enriched by looking at grandmother-mother paired interviews for transmission of attitudes about convenience food. The biggest loss was on the subject of choice, not convenience. Blaxter and Patterson (1983:103) noted that the younger generation (mothers) were more concerned about catering to tastes of family members (husbands and children) than their mothers (the grandmothers) had been. This would have been a rich vein to mine with my later questions on choice, but the data were not available to pursue that investigation. In sum, more data might have been better, yet the existing data yielded substantive findings. This result was not hugely different than I have felt at the end of most primary research.

\section{The interaction between sample expansion and topic refinement}

9.1 After analysing the Mothers and Daughters data, I wanted to explore new data. At the time, the total material in Blaxter seemed thin (though I later changed my mind about this). There was also simple curiosity: how extensive were ESDS Qualidata's holdings on convenience food and choice? I searched the catalogue using the single keyword of "food" and found nine studies. Six were eliminated because of either unsuitable data formats (audio) or less relevant topics, GM foods, food retailing, illness, etc. The criteria applied were general discussions of convenience food or choice and one collection remained, The Edwardians.

9.2 The Edwardians collection offered a historical perspective, the food topics covered were wide ranging, and the sample large and representative. However, after reading selected interviews more thoroughly, it became clear that a narrow focus on uses of convenience foods or their justifications would not yield much: the time period described was simply too early for convenience food to be very typical, and it was valued for its shelf-life rather than convenience. Many of The Edwardians questions were quite structured in format: e.g., "Where were meals eaten?", "When was breakfast eaten?", and "Where did wife cook?". This resulted in rather limited elaboration in most of the replies. However, several questions exposed social dynamics of meals: "Was mother served less? Did the knife have to be held a certain way? Could you choose what to eat? Could you talk, read or bring a toy to the table?" It was the question about choice that stood out:

"Could you choose what you wanted to eat from what was cooked or did you have to eat a bit of everything?" My research process thus took a meandering, but not atypical, path to reassess what data were relevant. The data reassessment combined with shift in topical focus, as my research questions were also revised.

9.3 Several threads intersected to produce this reassessment: a tentative finding from the Blaxter data, a surprising statistic from journalistic writing about food, and a theoretical thread from academic writing on food and identity. The Blaxter data had revealed relatively poor, working class, not-highly educated Scottish grandmothers to be fairly knowledgeable about healthy food practices such as the need to limit fats, sugar, and highly refined foods and the benefits of fresh fruit and veg. Though low quantities of fruit and fresh salads were eaten, vegetables were praised and used in abundance (in quantity if not always variety) in soups. Without being systematic, this confirmed an intuition I had that neither ignorance about nutrition nor

lack of maternal concern about children's' diets could be the primary explanation for growing reliance on convenience foods. Scottish grandmothers demonstrated love with soup, or more generally, with nourishing, simple, economical meals. Modern mothers, I speculated, had similar motivations, but competing demands (paid work, driving kids to football practice, etc.) led them to express their maternal love by catering to individual food tastes. Simplicity and frugality were being replaced by preference, diversity and choice, even at the expense of nutritional quality. I suspected connections among individuated eating, convenience foods, and the discourse of "choice" as a ubiquitous mantra of neoliberalism.

9.4 The second element that affected this topic shift was the growing frequency with which I was seeing individuated eating mentioned in the media. The practice of preparing customised dishes for several family members at a single meal, what I describe as "individuated eating", seemed to be frequent (de Vault, 1991;

Mintz, 1984, Palojoki and Tuomi- Gröhn, 2001; Valentine, 1999). De Vault found it so often she called it "double cooking." A You Gov survey found that $43 \%$ of mothers make up to three different meals per night

"to cater for fussy eaters" (Jones, 2005). Without making any causal claims, there is a link with convenience foods, as women in the labour force simply do not have time to prepare multiple meals without relying on convenience foods such as frozen and ready meals. 
9.5 Finally, there was a thread in sociological theory that described preferences for junk and convenience foods as expressions of choice, and thus, agency, and therefore necessary for identity formation (Gofton,

1995; Valentine, 1999). Much of this work lies in sociological traditions that identify consumption with practices of identity formation and choice with freedom (Tomlinson, 1990; Baumann, 1988). There are at least two concerns raised by an unreflective acceptance of the factor of choice. First, it reifies the freedoms associated with choice and pays too little attention to factors that structure such choices (Warde, 1994;

Bourdieu, 1984). Second, theories that emphasise consumption as expressions of agency and identity must be understood within the larger ideological context of neoliberalism's approbation of individualism and

choice (O'Neill 1999, Frank 2000, Crompton and Scott, 2005). Thus, very preliminary findings, grey literature, and theoretical speculation led me to refine my topic and investigate choice and its connections, if any, with convenience.

9.6 Early data analysis and further reading of both popular and academic sources resulted in a shift in my emphasis from convenience food per se, to using convenience food as a probe for understanding domestic food consumption as a setting in which the discourse of "choice" is enacted. With this shift, The Edwardians data became relevant and were added to the project. While The Edwardians data were not helpful on convenience foods, they did provide an opportunity to examine patterns of choice at meals. The issue of choice at meals seemed a reasonable precursor to individuated eating, and as a fallback, the representative sample meant being able to make some statistically generalisable claims about meals and dining practices.

9.7 To summarise: regarding sample expansion and topic development, how did reusing data compare with primary research? The flexibility and multiple influences I encountered were certainly typical of secondary research. As Heaton (2004:59) noted, "far from treating qualitative data as given, researchers frequently reshaped it to fit the purposes of the secondary study". With respect to primary research, I also think that especially in early stages of research, similar adaptations and extensions of the sample occur. At least my experience seems consistent with other descriptions of rather non-linear data acquisition processes, i.e., bricolage (Denzin and Lincoln, 2000)

\section{Relating to transcripts}

10.1 It might appear that the absence of the secondary researcher from the interview is the definitive differentiator between using and reusing data. Some infer that any reuse of data must make the realist assumption that data are "out there" (Mauthner, et al. 1998). Yet even this difference-researcher as present or not-blurs after some reflection. All qualitative analysis must address the issue that once the interview is done, any subsequent data construction happens with artifacts (memory, transcripts, audio or video tapes), not the actual interview (Lyon, 2003). While not diminishing the implications of not "being there", all qualitative researchers produce some (usually most) of their data through engagement with these artifacts.

10.2 Whether the researcher did the interview or not, questions arise when facing a transcript: how was it transcribed, by whom, with what kind of notation, using what conventions? What was deemed significant enough to record? The room? Clothing? Gestures? Pauses? Whether reading transcripts of one's own interviews or others, these questions have to be addressed during analysis. The Edwardians and Mothers and Daughters transcripts were used quite differently in this project, driven both by characteristics of the transcripts themselves and the particular questions I asked of them.

10.3 The Edwardians data were too old to have many substantive comments on convenience foods or processed foods of any kind. The question on choice of foods as meals generating at most a few sentences of reply, and thus seemed suited for simple categorisation only. Even though these interviews are oral histories and cover a wide range of subjects, there are not many long discursive replies, at least in the meals area.

I: You did have breakfast?

R: Oh, yes.

I: What did you have?

R: Oh, in the colder days porridge, Scotch Oats.

I: With something on it?

R: No, just porridge and a little brown sugar, you know.

I: No milk?

R: Well, not very often.

I: Anything else? 
R: A bit of margarine.

I: And jam?

R: Yes, jam. Mother used to make jam.

10.4 In general, answers to questions are brief with little elaboration, making any more complex coding scheme unwarranted. Regarding choice at meals, there are no occurrences of totally individualised choice. However, a response was coded as positive if the respondents' preferences influenced the choice of one food item over another. It did not count as positive if the respondent simply refused to eat food deemed undesirable.

10.5 The representative nature of the sample argued for being able to make some statistically generalisable claims about the questions of interest: frequency of shared meals, choice of foods at meals, and the presence of tinned foods. This piece of the analysis remained underdeveloped. Some potential exists for examining current sources of quantitative data on food consumption, e.g., the Expenditure and Food Survey, then assessing the possibility for longitudinal comparison with The Edwardians data.

10.6 The experience with Mothers and Daughters data was very different. The passages about food have an emotional intensity to them that comes through even in transcripts.

3G: Now my man now, he disnae [does not] believe in tinned food... he disnae believe in that either. He says there's nae [no] nourishment in that, you're better wi' your own. Even though you got a bone you could mak' a pot o' soup. A bone, you're getting' the goodness off a bone, the marrow, oot a bone.

10.7 There is no doubt that the decision to transcribe a Northeast Scots dialect adds depth to these interviews and enables a reader to "hear" the words. Blaxter (2006) noted that the grandmothers had varying degrees of dialect and in some cases, their speech would have been unintelligible to an "English" listener unfamiliar with the area. This transcription required great skill, much of it done by Elizabeth Patterson and

Sheila Murray. Their approach was to attempt to retain the flavour of the dialect and to subtly indicate respondents with more "educated" speech. The transcription includes only those words that most readers would know, such as bairns and didnae.

10.8 Another aspect of these transcripts is the eagerness (evidenced by quantity of speech) of some of the grandmothers to talk about food, and especially the merits of tinned, frozen and home-made foods.

Nowadays they get a tin an' there's nae eggs .in it an' the goodness is oot [out] o' it. Like... have you ever had frozen stuff an' you've cooked it an' you feel as though it didnae taste right... efter ha'in a fresh bit o' steak an' onion. Ken [know] fit [what] I mean? The juice... there's nae the juice in it. Well, that's whit we find wi' the things nowadays an' a, the richt good is out o' them... the body-buildin' material.. afore you eat it. I mean, tinned soup, I would niver hae it in the hoose unless it wis maybe Karen comin' in an' I wis gaun away in a hurry an' gettin' a tin o' soup... I wouldnae gie it to him... we were nae brought up like that, we wis brought up to get $a^{\prime}$ thing oot o' the groun' and intae a pot...

10.9 Other researchers have commented on the role of serendipity, and serendipity is relevant in both primary and secondary research. Where respondents are motivated to speak at length unprompted, one can infer a kind of intensity to the points they are making. One can be more confident that the ideas expressed are not put there by researchers' wishful thinking or influence (Bornat, 2003; Fielding 2004). In this case, there is little doubt that the comments about food were not solicited: tinned food was not a central topic in the primary research and the secondary researcher was not present!

10.10 The initial coding of attitudes toward convenience food was fairly straightforward. Then I looked for more complex narratives where the grandmothers' expressed moral condemnation, but qualified these statements with examples of permissible use of convenience foods. Interestingly, Blaxter and Patterson (1983) noted similar discrepancies, citing that some grandmothers approved of long-established brands of convenience foods (Oxo cubes) while extolling the superiority of home-made cooking. However, they did not systematise their observations throughout the sample. Their primary focus was on child-rearing, not food, and even in their food article, they structured their analysis on the generational comparison, with a focus on food for children. In my project, I was focused exclusively on food, and on the discussions of tinned food and convenience especially. Secondarily, as I did not have the daughter data for comparison, withinsubsample analysis of just the grandmothers was my only option. Put simply, we were co-constructing different data.

10.11 In sum, co-construction of data happens with secondary analysis, but in different ways. By definition, reflexivity about the actual encounter in real time is not possible. However, there is still the encounter with the transcript, sometimes the audio-tape, and supporting materials. Data are recontexualised and coconstructed whether reading transcripts or doing an interview in real-time. 


\section{Conclusion}

11.1 To summarise: what were some of the key similarities or differences I found between using and reusing data? Across most of the typical phases of research such as defining questions, locating data, and sampling, I found the actual practice of doing secondary analysis very similar to working with primary data. What was most familiar was the sense of always working back and forth: from questions to data and back, from one data source to another, and from data to explanations (hypotheses, concepts or mere hunches) and back. I came to think of this as bricolage made systematic by reflexivity. On balance, I found a far stronger sense of familiarity than foreignness.

11.2 However, there were substantive differences. While all qualitative data is constructed within a context, reusing data adds dimensions to that recontextualisation process, both across time and across two sets of research questions. Another difference is the greater sense of finiteness of the data. The experience of being able to probe in later interviews for themes that emerge early was constrained by not having data specific to my purpose and not being present at interviews. As my questions have sharpened, I recognise the need to collect primary data to address newly emerging research questions. Yet even as I write a proposal to do just that, I have found additional secondary sources, specifically on shopping for and preparing convenience foods, that I intend to examine as well. Perhaps most important, it is hardly unique to secondary analysis to call for further data collection on new research questions at the conclusion of a project.

11.3 This paper has presented a reflexive account of a secondary analysis of qualitative data. Throughout, the comparison with primary analysis has been noted, implicitly or explicitly. One might think that differentiating them would be easy. One position posits that for secondary analysis, the researcher "was not there," i.e., did not have a personal relationship with respondents. However, there are many situations in primary analysis where this is also true, e.g., teams where interview work is distributed, as was the case for The Edwardians research.

11.4 Another perspective on secondary analysis is Heaton's (2004) label of "pre-existing data". However, if qualitative data are constructed during research, not found, then the line blurs. If data are constructed, does that happen while reading background literature, while creating a sample, during an interview, while reading a transcript, or while composing an analytical memo? Of course, data are constructed during all these phases. In secondary research, the interview experience itself is missing. But all qualitative research has to deal with gaps (Fielding, 2001). I do not want to diminish this significance, merely to situate it. I make these points to suggest that that case is not black and white and thus merits the (I hope) more nuanced exploration I have attempted here.

11.5 While acknowledging significant distinctions between primary and secondary analysis, I suggest that more analytical traction is to be gained by moving beyond the polarised language of dualism, as Moore

(2005) recommends. For any qualitative analysis, context is critical in constructing the data; what is different when there are two contexts and two different research questions. For any qualitative analysis, interviews end and most construction happens with their textual, audio or visual records. Although differences exist regarding the researcher-respondent relationship, primary and secondary analyses are more alike than not. The suitability of each approach can only be assessed in light of a particular research question. Hence, this paper developed the argument through a particular reflexive account.

11.6 Given that qualitative methodologies, and presumably researchers, are supposed to be exceptionally capable of achieving in-depth understanding, discovering nuanced interpretations, and grasping complex relationships, it is more than a little ironic that the debate about primary and secondary analysis has become, at points, polarised (Bishop, 2005a; Corti and Thompson, 1998; Parry and Mauthner, 2004; Parry and Mauthner 2005). (However, I have found the debate less polarised and more nuanced in face-to-face conversations.) Often it seems that the intensity of the debate can be explained only by seeking other causes. In some cases, I suspect that the primary/secondary debate has become a proxy for other

debates: positivism/interactionism, realism/post-modernism, subjectivity/authorial authority, and even academic freedom/neo-managerialism (Moore, 2005). Whether or not these debates should be polarised is material for another paper. This paper has argued that secondary analysis should be assessed in detail and on its own merits. I hope this reflexive account has taken a small step in that direction.

\section{Acknowledgements}

I'm grateful for comments from Dawn Lyon, Niamh Moore, Mike Savage, Elizabeth Silva, members of BSA

Food Study Group-London branch, and Sociological Research Online reviewers and editors. I'm also indebted to Mildred Blaxter and Paul Thompson for making their data available, for encouraging my project, and for providing comments on this paper.

\section{References}


BELL, C. (2004) 'Doing Sociological Research: The Genre of 'Owning Up", International Journal of Social Research Methodology Vol. 7, No. 1, pp. 29-33.

BISHOP, L. (2006) 'A proposal for archiving context for secondary analysis', Methodological Innovations Online [Online], 1(2). Available: <http://sirius.soc. plymouth.ac.uk/ andyp/viewarticle.php?id=26>.

BISHOP, L. (2005a) 'Protecting Respondents and Enabling Data Sharing: Reply to Parry and Mauthner', Sociology, Vol. 39, No. 2, pp. 333-336.

BISHOP, L. (2005b) "'Oot o' the Groun' and Intae a Pot": Convenience food and choice in the 20th century.' BSA Conference presentation, York, March.

BLAXTER, M. (2006) Personal letter to Libby Bishop, 8 October.

BLAXTER, M., (2004) Mothers and Daughters: Accounts of Health in the Grandmother Generation, 19451978 [computer file]. Colchester, Essex: UK Data Archive [distributor], July. SN: 4943.

BLAXTER, M. and E. Patterson (1982) Mothers and Daughters: A three-generational study of health attitudes and behaviour. London: Heinemann Educational Books.

BLAXTER, M. and E. Patterson (1983) 'The goodness is out of it' in A. Murcott (ed) The Sociology of Food and Eating. Aldershot: Gower Press.

BORNAT, J. (2003) 'A second take: revisiting interviews with a different purpose', Oral History, Spring, pp. 47-53.

BOURDIEU, P. (1984) Distinction: A social critique of the judgment of taste . London: Routledge.

CHARLES, N. and Kerr, M. (1988) Women, Food and Families. Manchester: Manchester University Press.

CORTI, L. and P. Thompson (1998) 'Are you sitting on your qualitative data? Qualidata's mission'. International Journal of Social Research Methodology Vol.1, No. 1, pp. 85-89.

CORTI, L. and P. Thompson (2004) 'Secondary analysis of archived data' in C. Seale et al. (eds) Qualitative Research Practice. London: Sage, pp. 327-343.

CORTI, L., Witzel, A. \& Bishop, L. (2005) 'On the Potentials and Problems of Secondary Analysis. An Introduction to the FQS Special Issue on Secondary Analysis of Qualitative Data', Forum Qualitative Sozialforschung / Forum: Qualitative Social Research [On-line Journal], 6(1), Art. 49. Available at: $<$ http://www.qualitative-research.net/fqs-texte/1-05/05-1-49-e.htm>[Accessed 18.03.05].

CROMPTON, R. and J. Scott (2005) 'Class analysis: Beyond the cultural turn' in F. Devine, et al. (eds) Rethinking Class: Cultures, Identities and Lifestyle, pp. 186-203. Houndmills: Palgrave Macmillan.

DENZIN, N. and Y. Lincoln (2000) Handbook of Qualitative Research. London: Sage.

DE VAULT, M. (1991) Feeding the Family: The social organization of caring as gendered work. Chicago: Univeristy of Chicago Press.

DOUGLAS, M. (1972) 'Deciphering a Meal' Daedalus Vol., 101, pp. 61-81.

FIELDING, N. (2001) 'Automating the ineffable: getting the maximum from archived data', Celebrating British Sociology-ESDS Qualidata Symposium, July 5-6.

FIELDING, N. (2004) 'Getting the most from archived qualitative data: Epistemological, practical and professional obstacles', International Journal of Social Research Methodology, Vol. 7, No. 1, pp. 97-104.

FIELDING, N. and Fielding, J. (2000) 'Resistance and adaptation to criminal identity: using secondary analysis to evaluate classic studies of crime and deviance', Sociology Vol. 34, No. 4, pp. 671-689.

FRANK, T. (2000) One Market Under God. New York: Doubleday.

GOFTON, L. (1995) 'Convenience and the moral status of consumer practices' in D. Marshall (ed) Food Choice and the Consumer pp. 153-181, London: Blackie Academic \& Professional.

HAMMERSLEY, M. (1997) 'Qualitative data archiving: Some reflections on its prospects and problems.' Sociology Vol. 31, No. 1, pp. 131-142.

HEATON, J. (2004) Reworking Qualitative Data. London: Sage.

HARVEY, M., et al. (2002) Exploring the Tomato. Cheltenham: Edward Elgar.

HINDS, P., Vogel, R. and Clarke-Steffen, L. (1997) 'The possibilities and pitfalls of doing a secondary 
JONES, S. (2005) 'Hardworking supermums beat 1950s counterparts', The Guardian, 16 August, <http://www.guardian.co.uk/print/0,3858,5263193-103690,00.html>

LANG, T., M. C., P. Dixon and R. Carr-Hill (1996) 'Class, income and gender in cooking' in J. Edwards (ed) Culinary Arts and Sciences, pp. 415-426, Southampton: Computational.

LYON, D. (2003) 'The Making of Careers: Women and men in business and politics in Britain, Belgium and France', Unpublished PhD thesis, Department of Social and Political Sciences, European University Institute, Florence, Italy

MAUTHNER, N.S., Parry, O. and Backett-Milburn, K. (1998) 'The data are out there, or are they? Implications for archiving and revisiting qualitative data', Sociology Vol. 32, No. 4, pp. 733-745.

MAUTHNER, N. S. and A. Doucet (2003) 'Reflexive Accounts and Accounts of Reflexivity in Qualitative Data Analysis.' Sociology Vol. 37, No. 3, pp. 413-431.

MINTZ, S. (1984) 'Meals without grace', Boston Review, December 6-7.

MINTZ, S. (1985) Sweetness and Power: The place of sugar in modern history. New York: Penguin.

MOORE, N. (2005) '(Re)using qualitative data? Thoughts from the CRESC Qualitative Research Laboratory', paper for Reusing Qualitative Data Workshop, CRESC, Manchester, 28 Sept.

MURCOTT, A. (1982) 'On the social significance of the 'cooked dinner' in South Wales', Social Science Information Vol. 21, pp. 677-695.

MURCOTT, A. (1983) "It's a pleasure to cook for him': Food, mealtimes and gender in South Wales households' in E. Gamarnikow et al. (eds) The Public and the Private. London: Heinemann.

MURCOTT, A. (1995) 'Raw, cooked and proper meals at home' in D. Marshall (ed) Food Choice and the Consumer, pp. 219-233, London: Blackie Academic \& Professional.

MURCOTT, A. (ed) (1998) The Nation's Diet: The social science of food choice. Harlow, Essex: Addison Wesley Longman, Ltd.

MURCOTT, A. (2000) 'Is it still a pleasure to cook for him?', Journal of Consumer Studies and Home Economics Vol. 24, pp. 78-84.

O'NEILL, J. (1999) 'Economy, equality and recognition', in L. Ray and A. Sayer (eds) Culture and Economy after the Cultural Turn pp. 76-91, London: Sage.

PALOJOKI, P. and Tuomi- Gröhn, T. (2001) 'The complexity of food choices in an everyday context', International Journal of Consumer Studies Vol. 25, No. 1, pp. 15.

PARRY, O. and N. Mauthner (2005) 'Back to Basics: Who Re-uses Qualitative Data and Why?' Sociology Vol. 39, No. 2, pp. 337-342.

PARRY, O. and N. S. Mauthner (2004) 'Whose Data Are They Anyway? Practical, Legal and Ethical Issues in Archiving Qualitative Research Data.' Sociology Vol. 38, No. 1, pp. 139.

PERSONAL NARRATIVES GROUP (ed), B. J. Webster et. al. (1989) Interpreting Women's Lives: Feminist Theory and Personal Narratives. Bloomington: Indiana University Press.

RITSON, C. and R. Hutchins (1995) 'Food choice and the demand for food', in D. Marshall (ed) Food Choice and the Consumer pp. 43-76, London: Blackie Academic \& Professional.

ROBERTS, H. (ed) (1981) Doing Feminist Research. London: Routledge.

SAVAGE, M. (2005a) 'Revisiting Classic Qualitative Studies', Forum Qualitative Sozialforschung / Forum: Qualitative Social Research [On-line Journal], 6(1), Art. 31. Available at: http://www.qualitativeresearch.net/fqs-texte/1-05/05-1-31-e.htm [18.03.05].

SAVAGE, M. (2005b) 'Understanding popular identities in post-war Britain: the case of social class', paper for Reusing Qualitative Data Workshop, CRESC, Manchester, 28 Sept.

SHORT, F. (2003) 'Domestic cooking practices and cooking skills: Findings from an English study', Food Service Technology Vol. 3, No. 3/4, pp. 177-185.

SILVA, E. (2005) 'Re-using qualitative data: what's [yet] to be seen?', paper for Reusing Qualitative Data Workshop, CRESC, Manchester, 28 Sept. 
SZABO, V. and Strang, V. (1997) Secondary analysis of qualitative data. Advances in Nursing Science Vol. 20, No. 2, pp. 66-74.

THOMPSON, P. (1975) The Edwardians: The remaking of British society. London: Routledge.

THOMPSON, P. and Lummis, T., Family Life and Work Experience Before 1918, 1870-1973 [computer file]. 5th Edition. Colchester, Essex: UK Data Archive [distributor], April 2005. SN: 2000.

THOMPSON, P. (2002) Interview with Mildred Blaxter, 'Pioneers of Social Research Series', 2 August, Cringleford, Norwich.

TOMLINSON, A. (ed) (1990) Consumption, Identity and Style. London: Routledge.

VALENTINE, G. (1999) 'Eating in: Home, consumption and identity', Sociological Review, Vol. 47, No. 3, pp. 491-524.

WARDE, A. (1994) 'Consumption, identity-formation and uncertainty', Sociology Vol. 28, pp. 877-898.

WARDE, A. (1997) Consumption, Food and Taste. Sage, London.

WARDE, A. (1999) 'Convenience food: Space and timing', British Food Journal Vol. 101, pp. 518-27. 